\title{
SODRONYKÖTÉL ANYAGMODELLJÉNEK KIDOLGOZÁSA
}

\author{
Jánoki András ${ }^{a}$, Safranyik Ferenc ${ }^{b^{*}}$, Kollár László ${ }^{c}$ \\ ${ }^{a}$ ELTE Informatikai, Kar, Savaria Müszaki Intézet, Gépészmérnöki BSc, 3. évf. \\ ${ }^{b}$ ELTE Informatikai, Kar, Savaria Müszaki Intézet, egyetemi docens \\ ${ }^{c}$ ELTE Informatikai, Kar, Savaria Müszaki Intézet, egyetemi tanár
}

\begin{abstract}
ABSZTRAKT
Munkánk fố célja acélsodrony mechanikai tulajdonságainak vizsgálata. Ennek megvalósításához univerzális anyagvizsgáló géphez csatlakoztatható befogókészüléket terveztünk. Elsóként 3D modellezô szoftver segítségével megterveztük a befogó készüléket, amit végeselem módszer segítségével szilárdságtanilag ellenőriztünk. Ez a készülék a kötélsúrlódás elvén múködik és a kereskedelmi forgalomban kapható befogók tulajdonságait ötvözi. Ennek segítségével $4 \mathrm{~mm}$ névleges átmérôjú, korrózióálló acélsodronyokat vizsgáltunk. Ez alapján meghatároztuk a vezetékek szakítószilárdságát és közelítő anyagmodelljét.
\end{abstract}

Kulcsszavak: sodronykötél, anyagvizsgálat, anyagmodell, VEM

\section{Bevezetés}

Napjainkban a hideg éghajlati övezetben lévő területeken nagy problémát jelent az elektromos vezetékeken kialakuló jég- és hóréteg. Ezek az idôjárási tényezők statikus igénybevétellel terhelik a vezetéket, majd olvadáskor a hírtelen leesô tömeg rezgésbe hozza a kábeleket, dinamikus igénybevételnek teszi ki óket. A hosszabb vezetékek esetén méteres kilengések is elófordulnak ezek pedig az esetek egy részében tönkremenetelhez vezetnek. A jelenleg is alkalmazásban lévő távtartók páros vagy négyes kábel csoportok esetén csökkentik a kilengések nagyságát, de ez nem szünteti meg teljesen a problémát és nem megoldás az önmagában futó vezetékekre [1].

Ezek a távvezetékek készülhetnek tömör és sodrott kivitelben. Általában az utóbbi kialakítást használják, mivel jobban ellenáll a többszöri hajlításoknak (1. ábra). Mechanikai tulajdonságok javítása érdekében sodrott szálak további sodrott elemi szálakból tevődnek össze. A réz és alumínium sodronyok helyett, néha acél erősítéses vagy teljesen acél alapanyagú vezetékeket készítenek [2]. Ezen tulajdonságok ellenére is fennáll a tönkremenetel esélye a szélsôséges körülmények között [3].

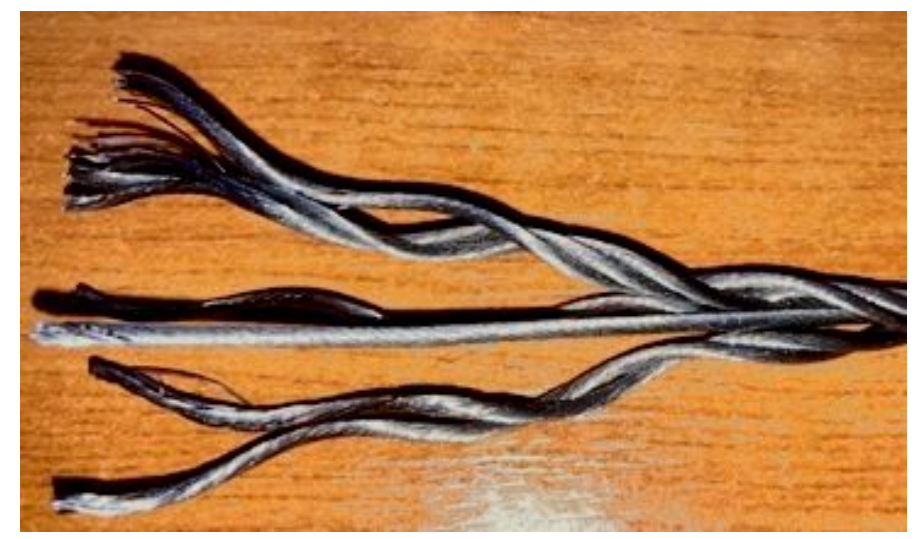

1. ábra: Acélsodrony

(C) ELTE, Informatikai Kar, Savaria Múszaki Intézet, 2021

*Kapcsolattartó: Safranyik Ferenc, sf@inf.elte.hu

https://doi.org/10.37775/EIS.2021.1.3 
A tönkremeneteli jelenség megértéséhez analitikus és numerikus modelleket is alkalmaznak a kutatók. A kutatásokban sokszor vizsgálják az elemi szálak kapcsolatát és a modell egyszerúsítésének lehetôségeit [3]. Mindkét modellhez először szükséges, hogy megismerjük a kábel viselkedését leíró anyagjellemzôket. Munkánk fô célja az elektromos vezetékként használt acélsodrony anyagmodelljének meghatározása anyagvizsgálatok alapján. Ehhez olyan befogókészüléket kellett tervezni, amely a Savaria Múszaki Intézetben rendelkezésre álló univerzális anyagvizsgáló berendezéshez illeszthető és alkalmas acélsodronyok rögzítésére.

Legfóbb szempontok a tervezéskor a költséghatékonyság, az egyszerú gyártás, könnyú szerelhetôség és a szakítógép maximális teljesítményének kihasználhatósága volt. Tanulmányoztuk a jelenleg használatban lévô konstrukciók egy részét. Ezek alapján több modellt készítettünk, amiket végeselem-módszer segítségével ellenôriztünk és a kapott eredmények alapján optimalizáltunk, így a befogó legyártása után lehetôségünk nyílt a vizsgálatok elvégzésére. Második lépésként a vezetékeken végzett mérésekból származó adatok alapján meghatároztuk a sodrony anyagmodelljét.

\section{Befogókészülék tervezése}

A befogó megtervezése előtt három már kereskedelmi forgalomban kapható kivitelt hasonlítottunk össze. Ezek mind a kötélsúrlódás elve alapján múködnek, ám a kábelvég rögzítése más-más módon történik. Az általunk tervezett befogó fô célja a 13 mm-es átmérôjú vezeték megfelelő rögzítése a szakítóvizsgálat során. Ezenkívül fontos volt, hogy a készülék csatlakoztatható legyen az egyetemen található univerzális anyagvizsgáló géphez és le tudjuk gyártani az egyetem gyártástechnológia laboratóriumában.

A funkcionális tervezést a Solid Edge 2020 3D tervezô program segítségével végeztük. A sodrony rögzítését egy menetes henger teszi lehetôvé, amire 2,5 menetet lehet felcsavarni így elég nagy az átfogási szög ahhoz, hogy megfelelően rögzíteni lehessen a sodronyt. A vezeték végének a rögzítését egy szorító pofa segítségével oldottuk meg, amit egy csavar szorít a másik pofához. A kötélsúrlódás összefüggése alapján meghatározható a rögzített kötélágban ébredô erô és ezáltal a szükséges csavar mérete, amely biztosítani tudja a szükséges szorítást. A húzóerôt a készüléken vizsgálható legnagyobb, 13 mm átmérôjû vezeték elszakításához szükséges erô alapján határoztuk meg, ami $F_{h}=75000 \mathrm{~N}=75 \mathrm{kN}$ nagyságú. A nyugvásbéli súrlódási tényezônek pedig a szakirodalomban megtalálható, acél-acélsodrony érintkezéshez tartozó értéket használtuk [4]. Ezek alapján a rögzített ágban fellépő erő:

$$
F_{r}=\frac{F_{h}}{e^{\mu_{0} \alpha}}=3241,04 \mathrm{~N}
$$

ahol: $\quad-\mu_{0}=0,2$, a nyugvásbéli súrlódási tényező [4],

- $\alpha$, az átfogási szög radiánban.

A kötélágban számított erô alapján 10.9 szilárdsági osztályú M8 névleges méretú csavart alkalmaztunk a kábelvég rögzítésére. A készülék rögzítőfelülete a szakítógép csapjának méretei alapján készült úgy, hogy a befogó könnyen cserélhetô legyen (2. ábra). A 3D modellt felhasználva a végeselemes ellenőrzéseket az Ansys szoftver statikus szerkezeti modulja segítségével végeztük [5]. Ennél a vizsgálatnál hegesztéseket nem ábrázoltuk a modellen és mivel a szorítóelem nem teherviselő így azt sem vettük figyelembe. $75 \mathrm{kN}$ nagyságú terhelő erố a huzalon keresztül, a húzási egyenesben, hat a menetes henger első beszúrására. Ezt az erôt távoli erô lehetőséggel definiáltuk a húzási egyenesben. Az iránya a pozitív z tengely felé mutat. Valóságban a készülék egy csapra van felhúzva, így az $x$ és $y$ irányú elmozdulását az ezzel érintkező felületen korlátoztuk. A z irányú rögzítésért a csatlakozón átmenő csap felel, így furatának függóleges irányú elmozdulását korlátoztuk (3. ábra). Három kontakt beállítást alkalmaztunk a vizsgálat alatt ezek mind nyomatékbíró merev kényszerkapcsolat típusúak, amelyek nem engedik az alkatrészek elcsúszását és elválását. Ezeket a hegesztési varratok helyettesítésére alkalmaztuk. A hálózáskor 10 mm nagyságú, elsőfokú közelítésú, tetraéder alakú elemeket 


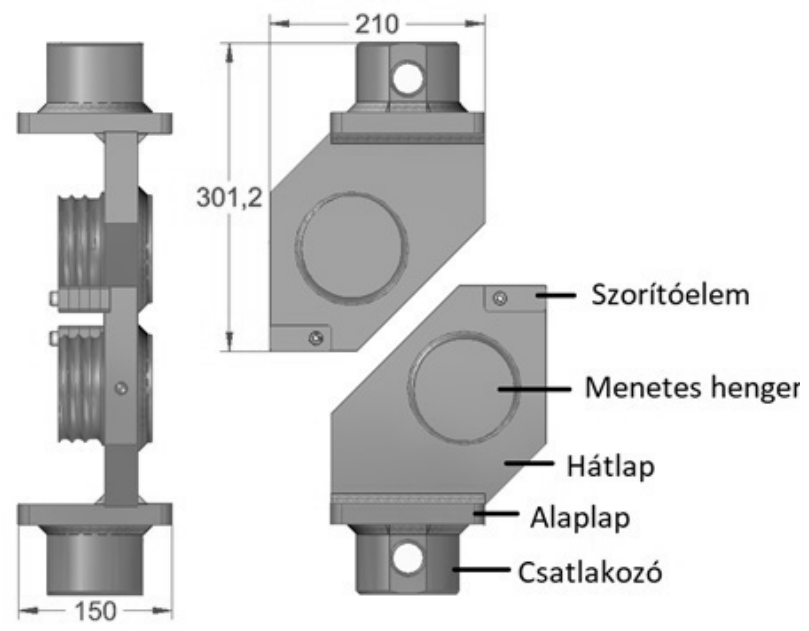

2. ábra: A befogókészülék háromdimenziós modellje és befoglaló méretei mm mértékegységben
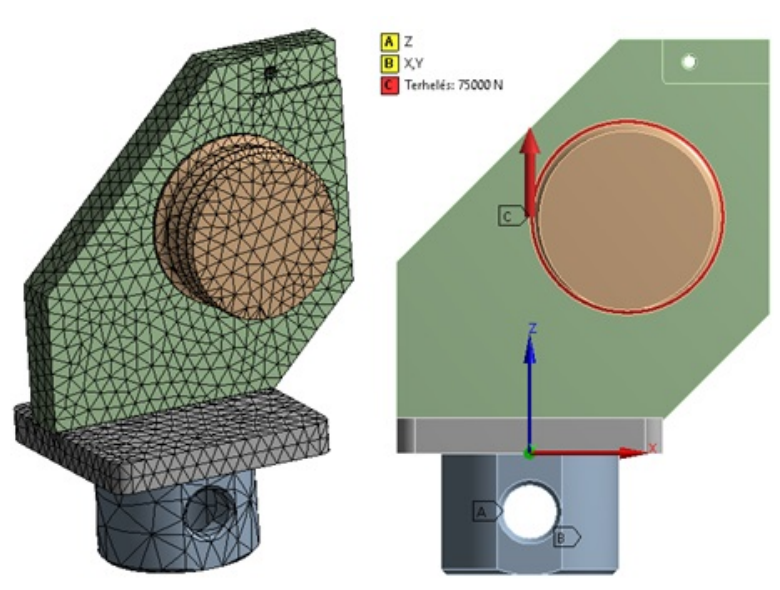

3. ábra: Végeselemes háló és peremfeltételek

alkalmaztunk, így 38222 csomópontszámot és 23515 elemszámot kaptunk. Ezekkel a beállításokkal elvégzett vizsgálatból azt kaptuk, hogy a legnagyobb redukált feszültség a hátlap és a menetes henger kapcsolatánál keletkezik az éles sarokban, ennek értéke 141,16 MPa (4. ábra).

A készülék valamennyi alkatrészét C45 minőségú szerkezeti acélból gyártottuk, amelynek folyáshatára $\left(R_{e H}\right)$ az előgyártmány méretei alapján 370 MPa. Vizsgálat során lineáris anyagmodellt használtunk, amihez 200 GPa értékû rugalmassági modulust és 0,3 értékú Poisson-tényezôt állítottunk be [6]. A legnagyobb szerkezeti feszültség $\sigma_{r e d, \max }=141,16 \mathrm{MPa}$, amelyek alapján biztonsági tényezôt számoltunk:

$$
n=\frac{E_{e H}}{\sigma_{r e d, \max }} \approx 2,6
$$

A fenti biztonsági tényező elfogadható, illetve mivel a maximális szerkezeti feszültség az éles sarokban ébredt, valóságban ennek értéke várhatóan kisebb lesz, a homorú hegesztési varrat feszültségcsökkentő hatása miatt. Végezetül a tervek és ellenőrzések alapján legyártottuk a befogókészüléket. Korrózióvédelemnek festést alkalmaztunk. Funkcióját tökéletesen ellátja és ezzel lehetôségünk nyílik kötél, huzal és fonal minták anyagvizsgálatára (5. ábra).

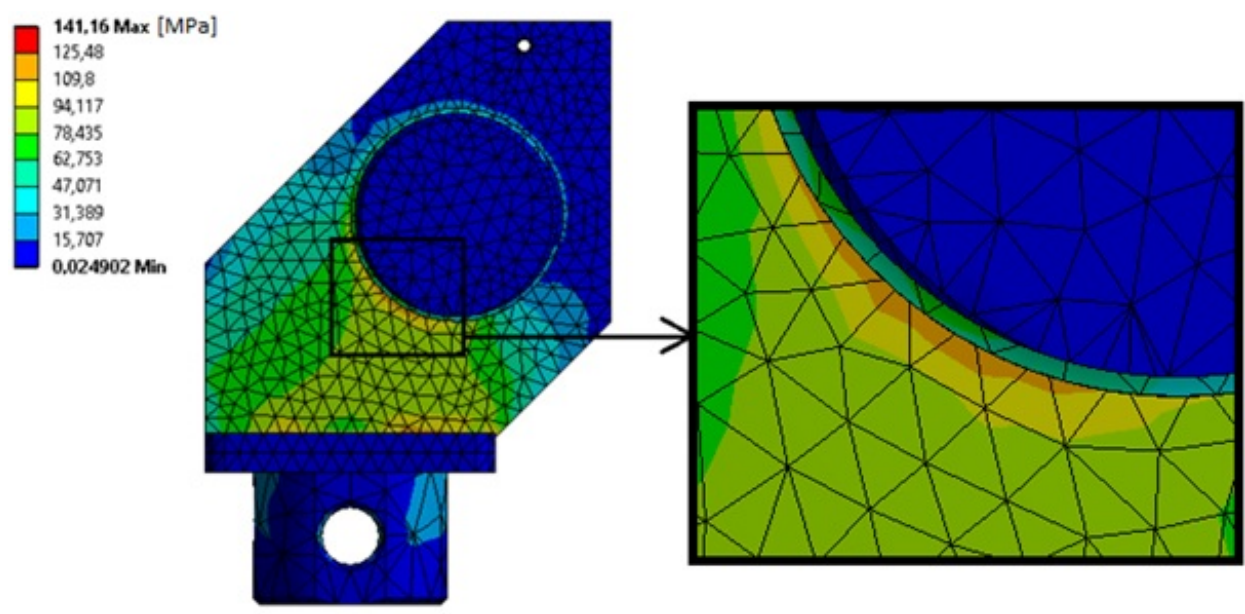

4. ábra: HMH-féle redukált feszültségek 

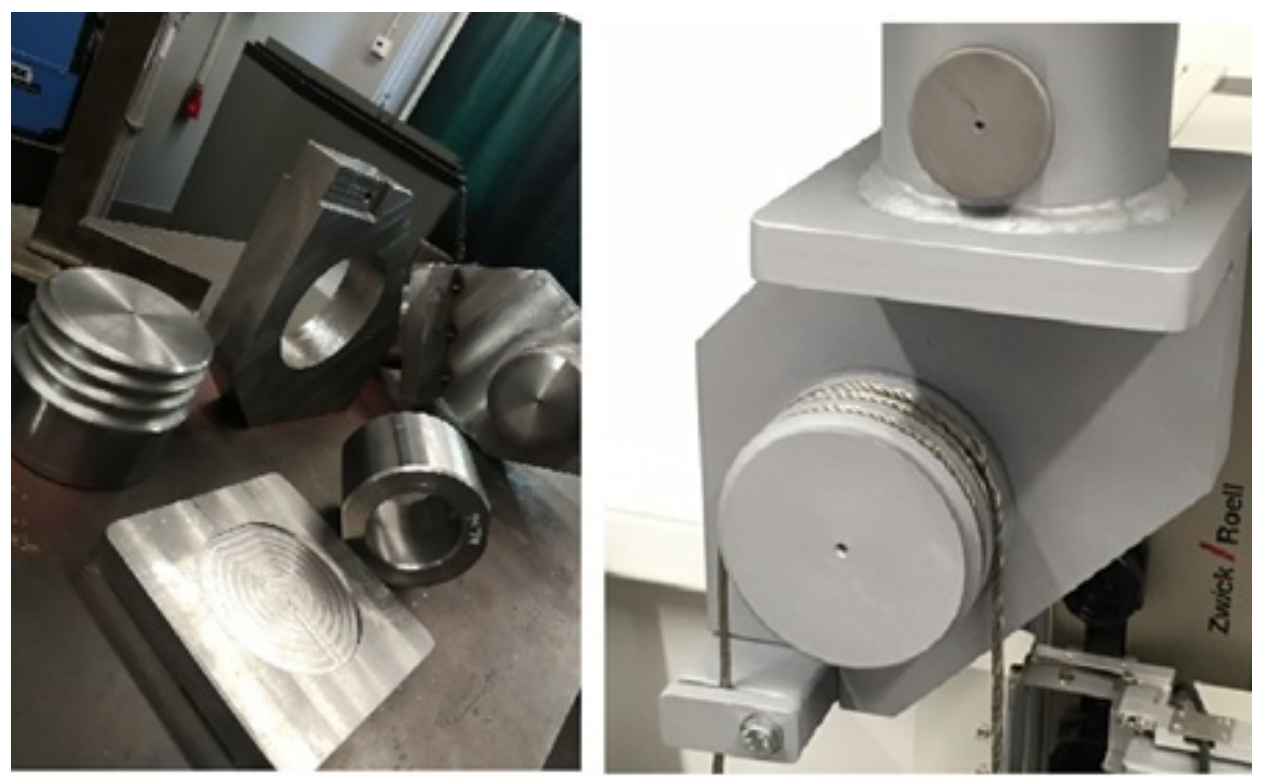

5. ábra: Az alkatrészek hegesztés elôtt és az elkészült befogókészülék

\section{Kísérleti vizsgálatok}

Az elkészült befogóval összesen 5 db mintán végeztünk anyagvizsgálatot. A vizsgálatokhoz az egyetemen található Zwick/Roell z100 típusú szakítógépet használtuk. Pontossága 0,2 kN - 1 kN között a mért érték 1\%-a, 1 kN felett pedig a mért érték 0,5\%-a. DIN3060 szabványú T7x19 méretú, $4 \mathrm{~mm}$ névleges átmérôjú, korrózióálló acélsodronyt használtunk az anyagvizsgálatokhoz. Ezeket az elnevezésből is meghatározhatóan 7 kisebb 19 szálból álló sodrott huzalból sodorták össze (6. ábra). Köré írható kör névleges átmérôje $4 \mathrm{~mm}$. A legkisebb szál kerekített átmérôje pedig 0,27 mm. Korrózióálló acélsodronyok szakítószilárdsága a szabvány szerint $1570 \mathrm{MPa}$ [7].

Mérési folyamat szempontjából fontos volt olyan hosszúra hagyni a kábeleket, hogy a két befogó között elférjen a mechanikus nyúlásmérő is, aminek segítségével mértük az alakváltozást. A kábel rögzítésekor fontos a kellő odafigyelés mivel rossz feltekerés esetén a szálak folyamatosan rendeződnek és csúsznak a készülékben, így hibás mérést eredményezve. Mindemellett arra is ügyelni kell, hogy a szorító pofán túl bôven legyen kábel mivel, ha a vezetékeket a végén fogjuk be, akkor a húzóeró hatására a kisebb szálak elkezdenek egymásról letekeredni így kilapul a keresztmetszet, aminek következtében elmozdul a rögzítésből a vezeték. Ilyenkor a mérési diagramon látható, hogy nem növekszik az erô és a kábel végén, mivel az elemi szálak szétbomlanak. A probléma a sodrony végére roppantható menetes véggel vagy megfelelő kinyúlási hossz alkalmazásával kiküszöbölhető. A megfelelő

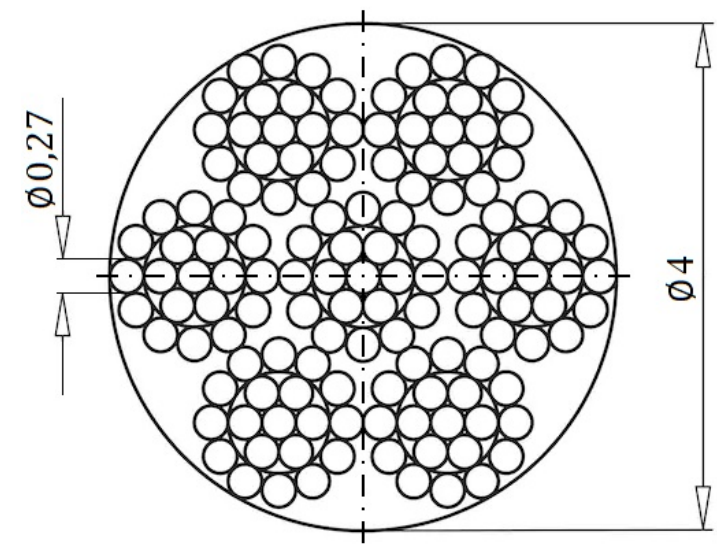

6. ábra: Vezeték és elemi szál keresztmetszete [8] 

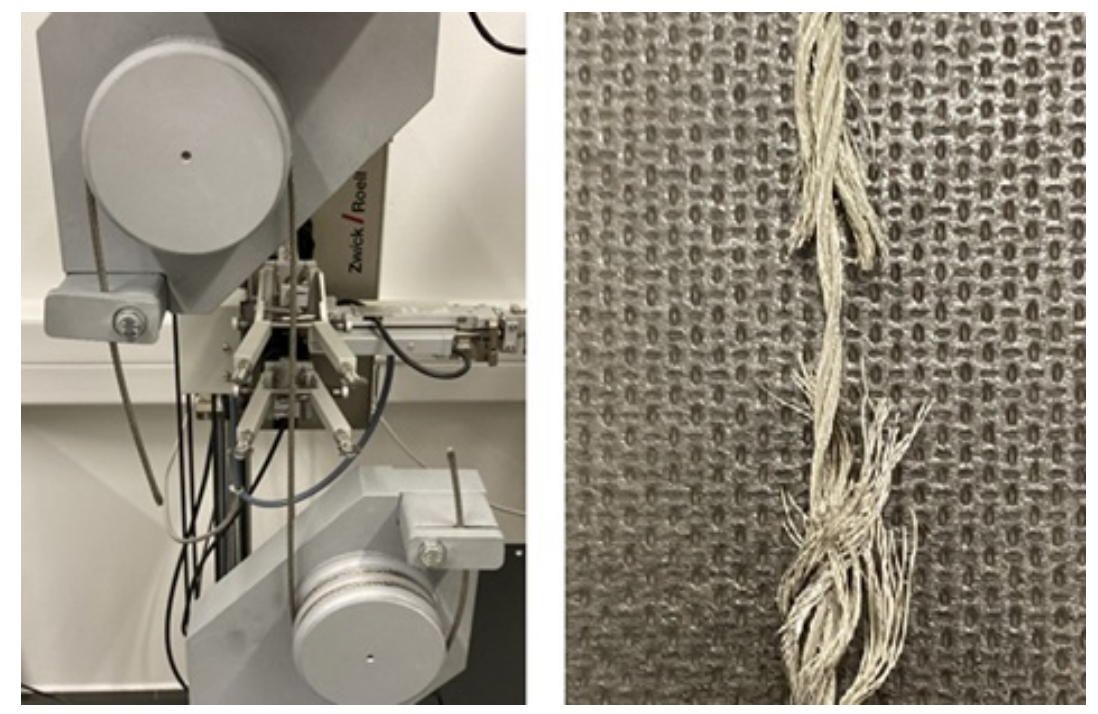

7. ábra: Acélsodrony mérés közben és a tönkremenetel után

befogás után a két befogót $5 \mathrm{~mm} /$ min-es sebességgel mozgattuk el egymástól. A szakítási folyamat végén megfigyelhető, hogy nem szakad el egyszerre az összes szál, bár ez várható volt a többszörösen összetett szerkezeti kialakítás miatt (7. ábra).

\section{Eredmények és következtetések}

A szakítóvizsgálat során megkapott adatokból megállapítható, hogy az elvégzett vizsgálatok között kicsi a szórás és közel egyformák a szakító diagramok (8. ábra). Méréseink alapján a sodronykötél szakítószilárdsága 1451,8 \ $29 \mathrm{MPa}$ (95,4\%-os valószínúséggel). A várható érték csupán 7,6\%-kal tér el a DIN 3060 szabványban szereplő 1570 MPa-os értéktől. Ezekból következik, hogy a befogókészülék megfelelôen használható és a mérési módszer alkalmas sodronykötelek vizsgálatára. Kapott adatokból további vizsgáltuk annak fontosságát, hogy a kábel keresztmetszetét lehet-e helyettesíteni a befoglaló kör területével. A sodronyt alkotó elemi szálak köré írható kör területe $A_{k}=12,57 \mathrm{~mm}{ }^{2}$. Ez jelentôsen nagyobb a vezeték pontos keresztmetszetének területénél, ami $A_{p}=7,61 \mathrm{~mm}^{2}$ (8. ábra). Ezt úgy kapjuk meg, ha összeadjuk a legkisebb elemi szálak keresztmetszetének területét. Ebből
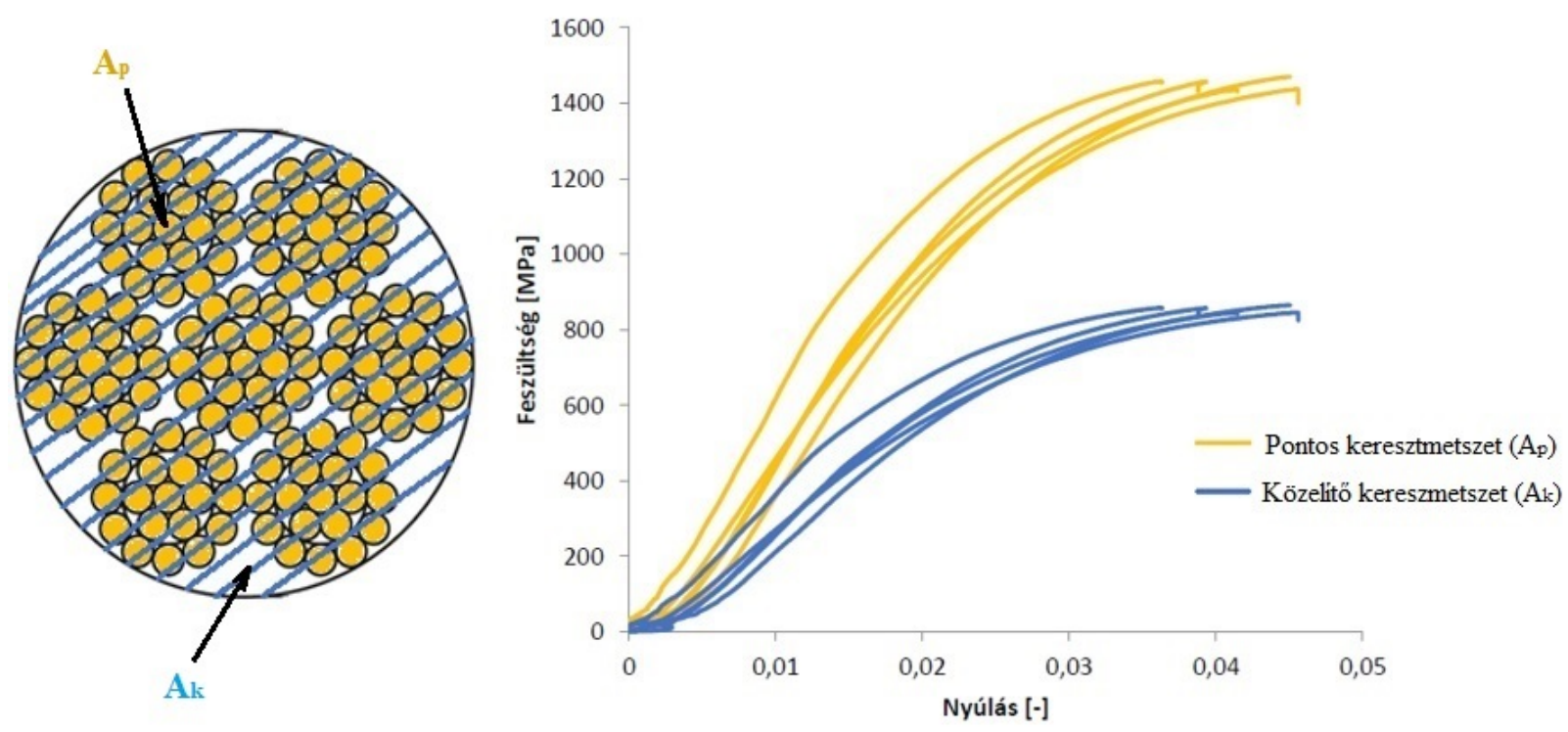

8. ábra: Vezetékben ébredô feszültség a pontos és közelítô keresztmetszet alapján 


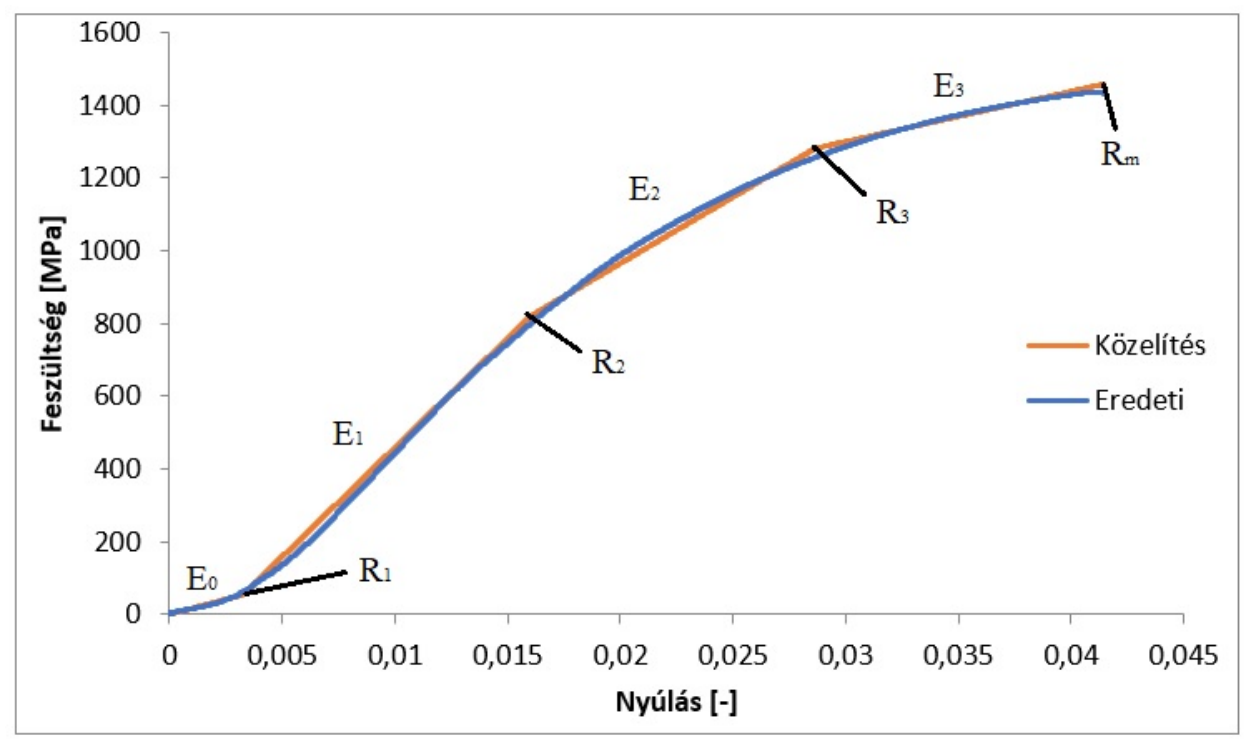

9. ábra: Szakítógörbék közelítése és a közelítés jellegzetes pontjai a valós keresztmetszet alapján

már látszik, hogy a két értékkel végzett számítások teljesen más eredményre vezetnek. Ezekkel a számokkal készítettük el a vezetékek feszültség nyúlás diagrammját, amirôl egyértelmúen megállapítható, hogy jelentôs különbségek vannak és a késóbbi vizsgálatokat fontos a pontos keresztmetszettel végezni (8. ábra).

Innentôl fogva az elemzéseket, csak a pontos keresztmetszetre terjesztettük ki. Következô lépésként az adatokból kapott görbéket 4-4 lineáris trendvonallal közelítettük hasonlóan Thoeni és szerzôtársai munkájához [9]. Ezek segítségével meg tudtuk határozni a görbe különbözô szakaszaira jellemző merevséget. Erre a kábel késóbbi végeselemes modellezésénél a megfelelően pontos anyagmodell beállítása végett van szükség (9. ábra). A számozott $R$ betúk a lineáris egyenesek metszés pontjai, a számozott $E$ betúk pedig egyes szakaszok meredekségét jelölik. Ez a meredekség az egyes szakaszokhoz tartozó merevségeket jelenti. Az $R_{m}$ az a pont, ahol vizsgálat során a vezeték elszakadt. Ebból adódóan ennek a pontnak a feszültség értéke a vezeték szakítószilárdságával egyezik meg.

\section{5. Összefoglalás}

Tervezés és VEM vizsgálatok után sikeresen legyártottuk a befogót, ami 0-13 mm átmérőjû vezetékek vizsgálatára alkalmas, 75 kN-os terhelésig, 2,6-os biztonsági tényezóvel. Ezután szakítóvizsgálatokat végeztünk és a kapott adatokból megállapítottuk, hogy befoglaló kör területével számolt feszültségek nagyban eltérnek a pontos területtel számítottól. A vezetékek 3,5-4,5\%-os alakváltozás után

1. táblázat: Mérési adatok és eredmények

\begin{tabular}{c|c|c|c|c|c|c|c} 
& 1. mérés & 2. mérés & 3. mérés & 4. mérés & 5.mérés & Átlag & Szórás \\
\hline$E_{0}[\mathrm{GPa}]$ & 16,56 & 17,46 & 48,07 & 14,26 & 25,13 & 24,30 & 13,91 \\
\hline$E_{1}[\mathrm{GPa}]$ & 61,18 & 56,76 & 68,07 & 63,20 & 54,28 & 60,70 & 5,42 \\
\hline$E_{2}[\mathrm{GPa}]$ & 36,50 & 34,35 & 38,37 & 34,90 & 31,48 & 35,12 & 2,57 \\
\hline$E_{3}[\mathrm{GPa}]$ & 14,47 & 14,32 & 15,21 & 13,37 & 11,49 & 13,77 & 1,44 \\
\hline$R_{1}[\mathrm{MPa}]$ & 54 & 79 & 87 & 51 & 71 & 68,4 & 15,61 \\
\hline$R_{2}[\mathrm{MPa}]$ & 799 & 967 & 847 & 899 & 869 & 876,2 & 62,51 \\
\hline$R_{3}[\mathrm{MPa}]$ & 1289 & 1286 & 1332 & 1393 & 1315 & 1323 & 43,50 \\
\hline$R_{m}[\mathrm{MPa}]$ & 1435 & 1470 & 1458 & 1457 & 1439 & 1451 & 14,52 \\
\hline
\end{tabular}


szakadnak el, miközben átlagosan 1 451,8 MPa feszültség ébred bennük. Ezek az eredmények a szabványban és a gyártók által megadott adatokkal összhangban vannak, így megállapítható, hogy a mérések sikeresek voltak.

\section{Köszönetnyilvánítás}

Jelen kutatás az EFOP-3.6.1-16-2016-00018 „A felsôoktatási rendszer K+F+I szerepvállalásának növelése intelligens szakosodás által Sopronban és Szombathelyen" címú projekt keretein belül valósult meg.

\section{Irodalomjegyzék}

[1] L.E. Kollár, M. Farzaneh, Vibration of Bundled Conductors Following Ice Shedding, IEEE Transactions on Power Delivery 23(2), 2008, pp. 1097-1104, CrossRef

[2] W.K. Lee, An insight into wire rope geometry, International Journal of Solids and Structures 28(4), 1991, pp. 471-190, CrossRef

[3] G. Kastratović, N. Vidanović, 3D finite element modeling of sling wire rope in lifting and transport processes, Transport 30(2), 2015, pp. 129-134, CrossRef

[4] M. Csizmadia Béla, Nándori Ernő, Mechanika Mérnököknek: Szilárdságtan (második kiadás), Nemzeti Tankönyvkiadó, Budapest-Gödöllö-Gyôr, 2002.

[5] Ansys@ Academic Research Mechanical, Release 16.0, 2016

[6] H. Mouradi, A.E. Barkany, A.E. Biyaali, Steel wire ropes failure analysis: Experimental study, Engineering Failure Analysis 91, 2018, pp. 234-242, CrossRef

[7] DIN 3060:1972, Acélsodronykötelek

[8] Würth szereléstechnika, letöltés dátuma: 2021. 01. 20, url

[9] K. Theoni, C. Lambert, A. Giacomini, S.W. Sloan, Discrete modelling of hexagonal wire meshes with a stochastically distorted contact model, Computers and Geotechnics 49, 2013, pp. 158-169, CrossRef 